\title{
Curbing the Labor Market Divide by fostering Inclusive Labor Markets through a Job Guarantee Scheme
}

Citation for published version (APA):

Klosse, S., \& Muysken, J. (2016). Curbing the Labor Market Divide by fostering Inclusive Labor Markets through a Job Guarantee Scheme. Psychosociological Issues in Human Resource Management, 4(2), 185-219. https://doi.org/10.22381/PIHRM4220168

Document status and date:

Published: 01/01/2016

DOI:

10.22381/PIHRM4220168

Document Version:

Publisher's PDF, also known as Version of record

\section{Please check the document version of this publication:}

- A submitted manuscript is the version of the article upon submission and before peer-review. There can be important differences between the submitted version and the official published version of record.

People interested in the research are advised to contact the author for the final version of the publication, or visit the DOI to the publisher's website.

- The final author version and the galley proof are versions of the publication after peer review.

- The final published version features the final layout of the paper including the volume, issue and page numbers.

Link to publication

\footnotetext{
General rights rights.

- You may freely distribute the URL identifying the publication in the public portal. please follow below link for the End User Agreement:

www.umlib.nl/taverne-license

Take down policy

If you believe that this document breaches copyright please contact us at:

repository@maastrichtuniversity.nl

providing details and we will investigate your claim.
}

Copyright and moral rights for the publications made accessible in the public portal are retained by the authors and/or other copyright owners and it is a condition of accessing publications that users recognise and abide by the legal requirements associated with these

- Users may download and print one copy of any publication from the public portal for the purpose of private study or research.

- You may not further distribute the material or use it for any profit-making activity or commercial gain

If the publication is distributed under the terms of Article $25 \mathrm{fa}$ of the Dutch Copyright Act, indicated by the "Taverne" license above, 


\title{
CURBING THE LABOUR MARKET DIVIDE BY FOSTERING INCLUSIVE LABOUR MARKETS THROUGH A JOB GUARANTEE SCHEME
}

\author{
SASKIA KLOSSE \\ s.klosse@maastrichtuniversity.nl \\ Faculty of Law, \\ Maastricht University \\ JOAN MUYSKEN \\ j.muysken@maastrichtuniversity.nl \\ (corresponding author) \\ School of Business and Economics, \\ Maastricht University; \\ UNU-MERIT
}

\begin{abstract}
Globalization, demographic trends and technological developments pose important challenges to European labor markets: job quality has deteriorated and precariousness has increased. Austerity measures enforced after the financial crisis have aggravated this trend. We argue that there is a case for appropriate active inclusion policies, complemented by stimulating macroeconomic policies. Using descriptive statistics and a systematic review of the literature, we propose to experiment with Job Guarantee (JG) projects. These projects could provide a macroeconomic stimulus to the economy by enabling everybody who is willing to work to take up a JG job at the minimum wage. Job guarantee projects are not a panacea to all evils. But experience shows that they could help to stop the casualization of the labor market by providing quality jobs and sustainable employment opportunities. As such, JG projects could foster inclusive labor markets. The projects should be financed by redirecting social security (administration) funds, by including JG elements in the European Investment Plan and by using part of the $€ 80$ billion which the European Central Bank (ECB) is injecting each month in the euro area. Our proposal aims to curb the labor market divide by making labor markets more "inclusive" through a solid Job Guarantee scheme.
\end{abstract}

\section{JEL codes: J48; E6; J21; J68}

Keywords: inclusive labor market policies; job guarantee; sustainable employment

How to cite: Klosse, Saskia, and Joan Muysken (2016), "Curbing the Labor Market Divide by Fostering Inclusive Labor Markets through a Job Guarantee Scheme," Psychosociological Issues in Human Resource Management 4(2): 185-219.

Received 25 May $2016 \cdot$ Received in revised form 2 August 2016 Accepted 2 August 2016 • Available online 25 August 2016 


\section{Introduction}

The combination of globalization, demographic trends and technological developments pose important challenges to European labor markets. In many European countries flexible employment patterns have become a dominant feature, leading to a growing number of people for whom flexible work, part-time work or self-employment is the only way to participate in the labor market. At the same time, the quality of jobs has deteriorated and precariousness has increased. Austerity measures enforced after the financial and economic crisis seem to have aggravated this trend. In this article we argue that there is a case for appropriate active inclusion policies, fostered by a Job Guarantee scheme and complemented by stimulating macroeconomic policies.

We share the widespread concern about the persistence of poverty and joblessness leading to apprehension about sustainable employment in the European Union. In that light the European 2020 Strategy moved the creation of more and better jobs and greater social cohesion to the top of the agenda, thereby emphasizing the importance of active policies to promote smart, sustainable and inclusive growth (COM 2010, 2020 and COM 2012, 173 final). Also the OECD is worried about labor market performance and wellbeing. In fact, the major part of its annual Labour Employment Outlook is devoted to questions presented in chapter titles like "Sharing the pain equally?" (OECD, 2014, Ch. 2), "How good is your job?" (OECD, 2014, Ch. 3), and the "labor market divide" (OECD, 2014, Ch. 4).

To illustrate these concerns we show in section 2 how over time the labor market situation in the European Union has deteriorated in terms of providing sustainable employment and better quality jobs. Although labor market participation has increased, in particular due to higher participation of women, this was mostly in low quality jobs. Moreover unemployment increased sharply after the crisis starting in 2008. The incidence of low quality jobs and unemployment is especially high among certain groups (youngsters and low education persons) and in some countries (Greece, Italy, Ireland, Portugal and Spain). Inclusive activation policies, leading to sustainable employment and better jobs, therefore are warranted.

We associate in section 3 the concern for inclusive activation policies with the notion of full employment which was dominant in the first decades after WWII in all European countries. We show how after the reforms in the 1980s this notion was replaced by the notion of "full employability," leading to less concern for the quality of jobs and to in-work poverty. The current policy stance on active inclusion is somewhere in between both notions. Moreover due to the financial crisis and the austerity measures, active inclusion policies seem to have stagnated. Both observations induce us to argue in favor of experimenting with a Job Guarantee Scheme as a leap forward to restore full employment. 
In section 4 we further develop the idea of introducing Job Guarantee Experiments with the aim to secure the availability of good quality jobs at the minimum wage level for all those who are able and willing to work. First we briefly discuss (positive) experiences with existing job guarantee programs, in particular in Argentina, India and the Netherlands and with the EU Youth Guarantee Scheme. We then propose to implement job guarantee experiments in the EU, thereby stressing the context of sustainable employment with quality jobs, consistent with the earlier introduced notion of full employment. Finally we argue that job guarantee experiments can be partly financed by redirecting social security (administration) funds and by including job guarantee elements in the European Investment Plan (also known as the Juncker Plan). We point out that this is a very good way to spend part of the $€ 80$ billion which the ECB injects each month in the euro area.

Section 5 concludes.

\section{Challenges for an Inclusive European Labor Market}

For obtaining full sustainable employment at least three preconditions need to be fulfilled. We will use these preconditions as backbone for our analysis of the challenges EU Member States are facing in terms of realizing inclusive labor markets. The first precondition is that persons have to be willing to look for a job. This shows up in the activity rate which we discuss in section 2.1. Second persons have to find a job. For that reason we look at the unemployment rate in section 2.2. Finally the jobs should lead to sustainable employment, that is, employment "promoting quality jobs and preventing in-work poverty" and "helping people stay in work and advance in their careers." Sustainable employment and the nature of jobs are discussed in section 2.3.

In our discussion we focus on the EU15 since for this group of countries data are available for a longer period (since 1995). For individual countries we compare the EU12, since for these countries data are available in most cases since the mid 1980s. ${ }^{2}$ Moreover, this group of countries covers the four types of welfare states distinguished in Urbé (2012, Ch. 1): the liberal "Beveridge" system (with Ireland and the UK), the conservative, corporatist "Bismarck" system (with Belgium, France, Germany, Luxembourg and, to a certain extent, the Netherlands), the social democratic or Scandinavian (Nordic) regime (with Denmark) and the "Mediterranean" Model which puts a larger burden of the social well-being on the family (with Greece, Italy, Portugal and Spain). 


\subsection{Labor force participation}

From Figure 1 one sees how the rate of labor force participation has been steadily increasing in the EU15, from $67 \%$ in 1995, of the population aged 15-64 years, to $73 \%$ in 2013. As is illustrated in Figure 2, the variation across countries is quite large in the EU12: It ranges from 63\% in Italy in 2013 to almost $80 \%$ in the Netherlands. Moreover, compared to 1986 participation did hardly increase in Italy, whereas it increased dramatically in the Netherlands and in Spain - by almost $20 \%$ in both countries.

Figure 1 Labor force participation and employment in EU15, 1995-2013

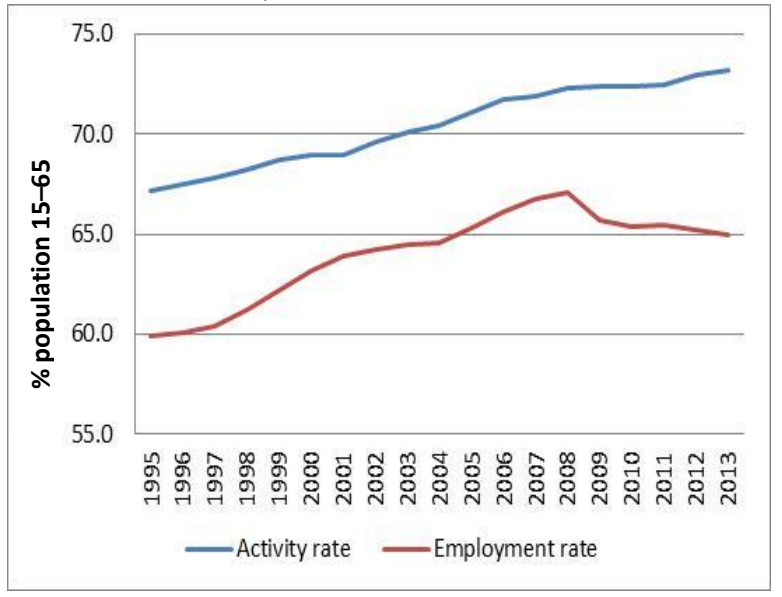

Figure 2 Activity rates of the EU12, 1986-2013

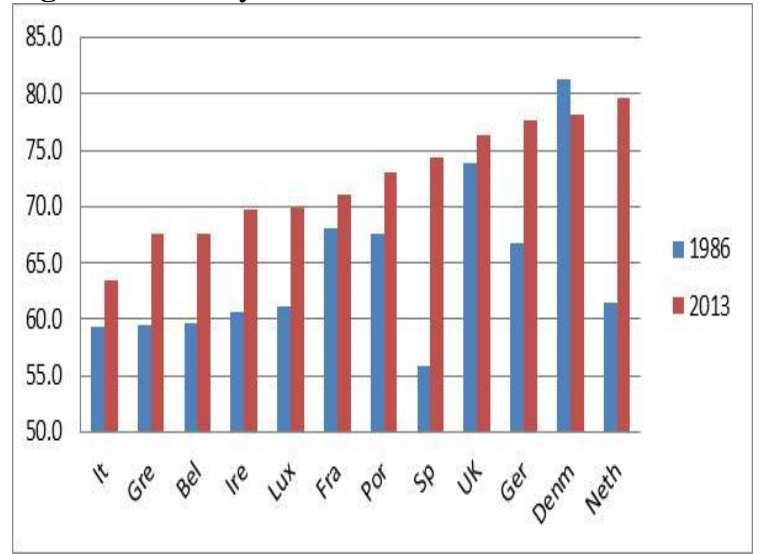


Figure 3 Reasons for inactivity in EU15, 1996-2013

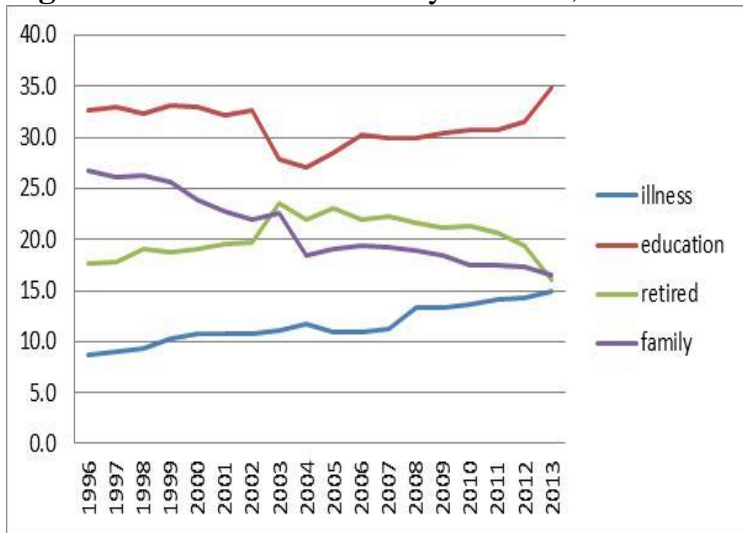

Figure 4 Reasons for inactivity in EU12, 2013

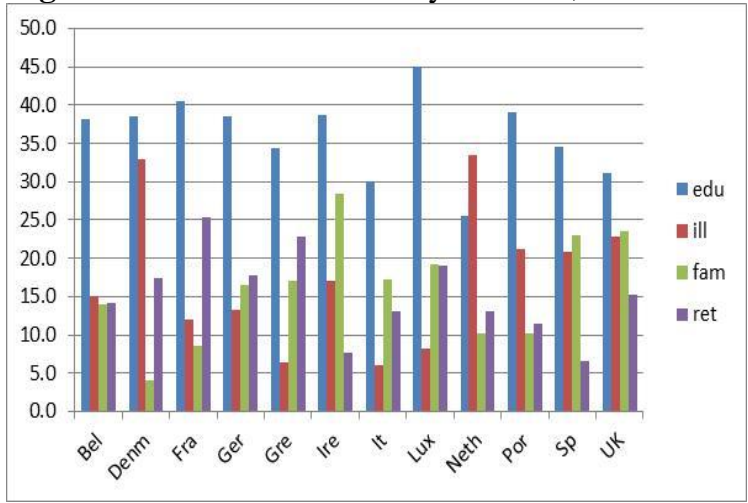

From Figure 3 one sees that the main reason for inactivity is education. The higher incidence of this reason since the economic crisis in 2008 is consistent with the notion that more young persons are extending their education in a situation of increasing unemployment (ILO, 2012). The second reason for inactivity is family-related, like looking after a child or dependent family member. The impact of this reason has declined systematically, reflecting an increasing participation of women on the labor market (often in part time work) - see Appendix A1. The impact of the third reason, early retirement, has decreased - this is consistent with increased labor participation of the age group 55-64 (Appendix A1). Finally, illness and disability have increased systematically as a reason for inactivity, with a small jump after the financial crisis.

The incidence of inactivity in the EU15 amongst educational groups is shown in Appendix A1. The high rate of inactivity amongst low educated persons is striking: labor force participation is less than $60 \%$, almost $20 \%$ below that of medium educated persons. ${ }^{3}$ Surprisingly enough, this phenom- 
enon is also observed amongst the young, aged 15-24. Finally, the country of birth has a low impact on labor force participation, as can be seen from Appendix 1.

The incidence of reasons for inactivity shows a large variation across countries as appears from Figure 4 (see also Appendix A2). Education is the dominant reason in all countries, except in the Netherlands, and has been increasing. Family reasons are above $20 \%$ in Ireland, the United Kingdom and Spain, but below $10 \%$ in the Netherlands, Portugal, France and Denmark. Retirement is above 20\% in France and Greece, but below 10\% in Ireland and Spain. The largest variation is found in illness and disability as a reason for inactivity, varying from over $30 \%$ in the Netherlands and Denmark, over $20 \%$ in the United Kingdom, Portugal and Spain, to far below $10 \%$ in Greece and Italy. Moreover the incidence of this reason has increased in all countries except the United Kingdom and Luxemburg.

When analyzing the reasons of inactivity no explicit attention is paid to the so-called discouraged worker effect. This is remarkable in view of the fall in the employment rate after the financial crisis in 2008 (see Figure 1). The increase in unemployment rates corresponds to a clear slow-down in the increase of the activity rate: Whereas it increased by $2.2 \%$ in the five years prior to the financial crisis, it increased by $0.9 \%$ only afterwards. The strong increase in unemployment after the financial crisis probably discouraged many potential job-seekers to enter the labor market (Watt, 2013; Christl and Kucsera, 2014).

\subsection{Unemployment}

As is well-known unemployment in Europe has risen dramatically in the aftermath of the financial crisis. In the EU15 unemployment decreased after the recession in the early 1990s from almost 11 to $7 \%$ in 2000, after which it remained stable till 2007 - see Figure 5. However, after the financial crisis in 2008 it rose sharply to a level above $11 \%$ in 2013. As can be seen from Figure 5 the rate of long-term unemployment also increased, even stronger than proportional.

In Appendix B we show some figures to illustrate that the unemployment incidence is higher amongst foreigners and young persons: in 2013 unemployment in EU 15 amongst the age group 15-24 was 32\% for foreigners compared to $23 \%$ for the total, and unemployment amongst foreigners in general was $18 \%$ compared to $11 \%$ for total unemployment. There are no clear gender differences in unemployment. 
Figure 5 Unemployment in EU15, 1995-2013

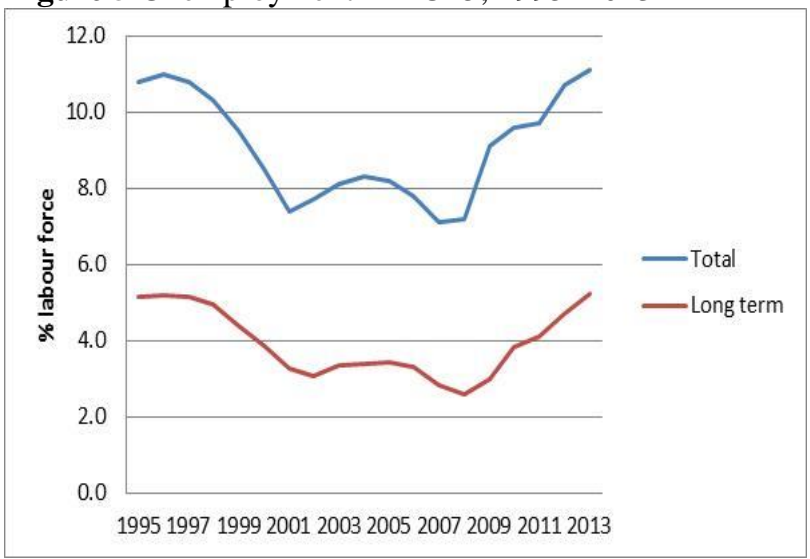

Figure 6 Unemployment in EU12, 1986-2013

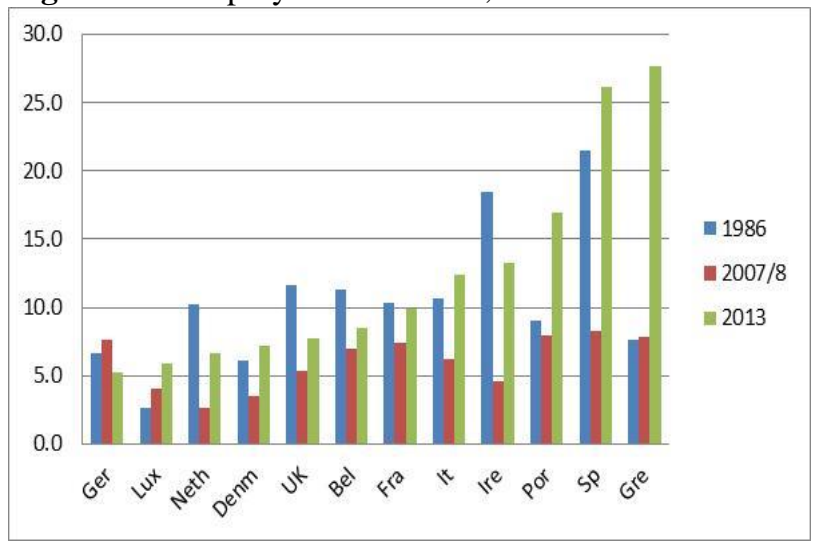

One observes from Figure 6 that there is a large variation in unemployment across countries after the financial crisis, ${ }^{4}$ compared to a much smaller variation just before the financial crisis. In particular Spain and Greece are severely affected, with unemployment rates above $25 \%$ in 2013 . The dramatic increase in unemployment in the so-called GIISP countries after the financial crisis (doubling in Italy and Portugal and tripling in Ireland, Spain and Greece) is in our view an indication that the main cause of unemployment is demand deficiencies imposed by austerity measures (Stiglitz et al., 2014; de Grauwe and Ji, 2015), rather than labor market rigidities, as the dominant view suggests. ${ }^{5}$ As we will argue below, this has important implications for the inclusive labor market policies. 


\subsection{Sustainable employment and quality of jobs}

As we mentioned in the introduction, a third precondition for realizing inclusive labor markets is the availability of sustainable employment and reasonable working conditions. We briefly analyze below the incidence of temporary employment, self employment and part-time employment, since they feature higher job insecurity and may hamper sustainable employment. We also consider the quality of jobs in the EU12 as represented by "in work at risk of poverty" and "physical and mental wellbeing at work."

Temporary work is an important threat to sustainable employment (OECD, 2014: 143). ${ }^{6}$ Yet, the incidence of temporary work has increased in the EU15 from just above $11 \%$ in 1995 to $15 \%$ in 2005 - see Figure 7. After the financial crisis it stabilized around 14\%. In Appendix C we show that there is a strong variety across the EU12 countries, with an incidence of above $20 \%$ in 2013 in Spain, Portugal and the Netherlands. In 2013 less than 20\% of the temporary workers in the EU15 indicates that temporary work is a voluntary choice and over $60 \%$ indicates that they accepted temporary work because they could not find a better job - see Figure $8 .^{7}$ Finally, OECD (2014: 143) notes that these jobs "are still disproportionately held by younger, less educated and lower-skilled workers."

Figure 7 Temporary and self-employment in EU15, 1995-2013

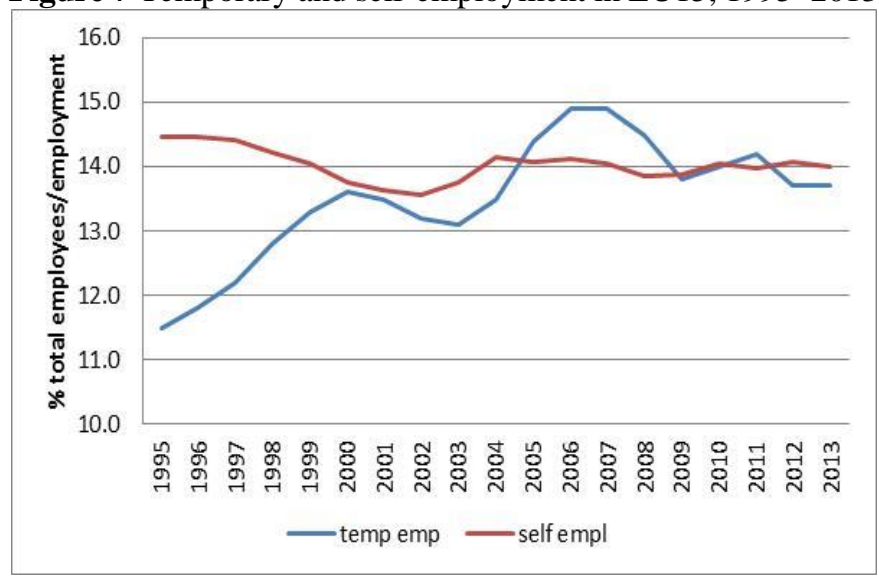


Figure 8 Reasons for temporary employment 1996-2013 in EU12

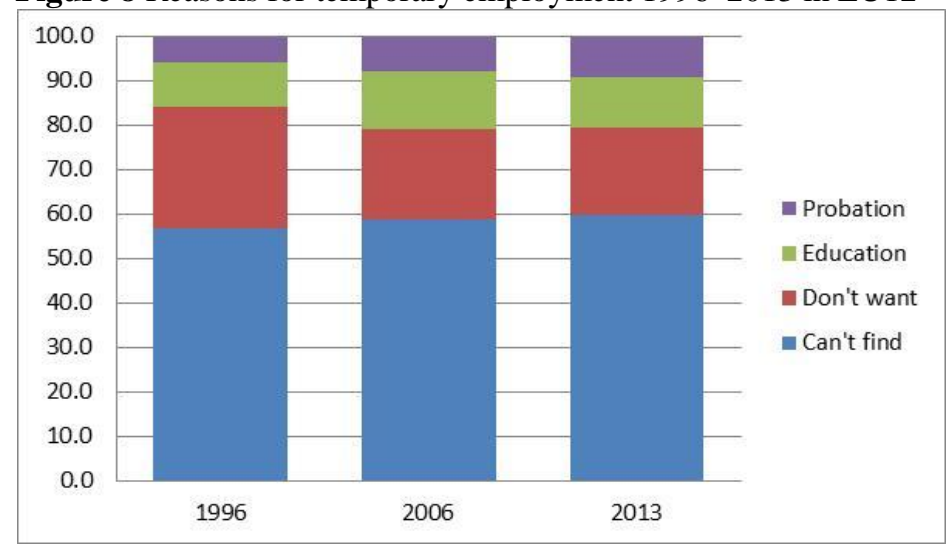

As appears from Figure 7, self-employment is also an important phenomenon in the EU15, representing about $14 \%$ of total employment. A substantial part of these self-employed consists of so-called own-account workers. However, the data are quite unreliable and provide an underestimation of their true number (OECD, 2014, Ch. 4) - we present these data for the EU12 countries in Appendix $\mathrm{C}$ - this shows that its incidence generally increased after the financial crisis. There are no further data available at European level to analyze the employment perspectives for this group in more detail, ${ }^{8}$ but as OECD (2014) observes this category of workers has de facto the lowest degree of job protection of all dependent workers. As they "are not employees, the labor standards or other protection conferred by labor law, are not normally applicable to them" (OECD, 2014: 169).

A final threat to sustainable employment is the increasing incidence of part-time work - see Figure 7. It is generally recognized that part-time work goes hand in hand with higher labor market insecurity (OECD, 2014, Ch. 3). It also can be involuntary since part-time persons might want to work longer hours than available on the job. One sees from Figure 8 that almost one third of the workers in EU15 indicate that part-time work has been accepted because no full-time job was available. This is probably an underestimation since part-time work due to "care" will be influenced by the availability of child-care facilities. The importance of "care" and "other family responsibilities" as reasons for part-time employment is consistent with the high incidence of female part-time workers as appears from Figure 7. 
Figure 9 Part-time employment in EU15, 1995-2013

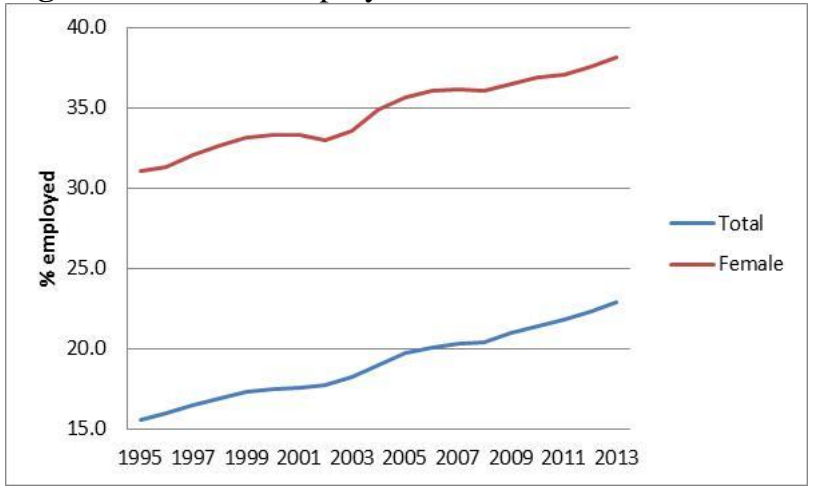

Figure 10 Reasons for part-time unemployment, 1995-2013 in EU12

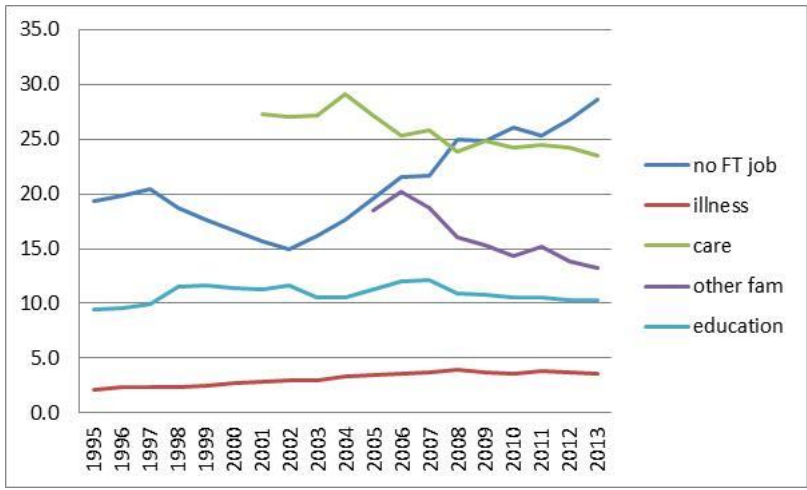

Turning to the quality of jobs, one of the indicators used by Eurostat is the so-called in work at risk of poverty, which is the share of persons who are at work and have an equivalized disposable income below the risk-of-poverty threshold. ${ }^{9}$ This share increased for the EU15 from $7.5 \%$ in 2005 to $8.6 \%$ in 2013. The variety of the share amongst the EU12 countries is large. One sees from Figure 11 that Greece, Italy, Portugal and Spain are amongst the five countries with a share above $10 \%$ in 2013 . Hence in these countries at least one out of ten persons who have a job, are at risk of poverty.

Another indication of the quality of jobs is negative wellbeing at work, measured by the share of persons reporting exposure to factors that can adversely affect physical or mental well-being. The results presented in Figure 12 for the EU12 are quite surprising, since not only the GIIPS countries score high on this list, but also the UK, the Netherlands and in particular France. We could not find a precise reason for this result. However, excluding the outlying result for France, the average reported negative wellbeing for the EU27 was 35\% in 2007 for physical reasons and 23\% for mental reasons. 
Figure 11 In work at risk of poverty in EU12, 2005-2013

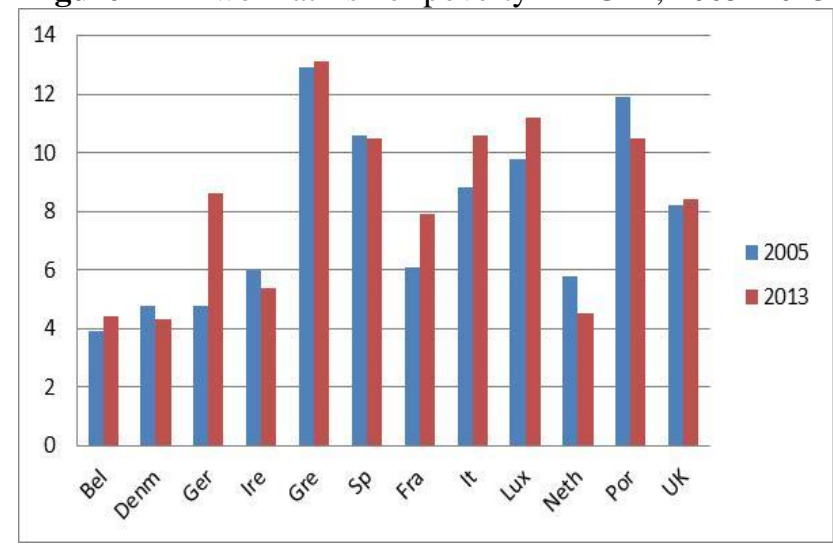

Figure 12 Negative wellbeing at work in EU12, 2007

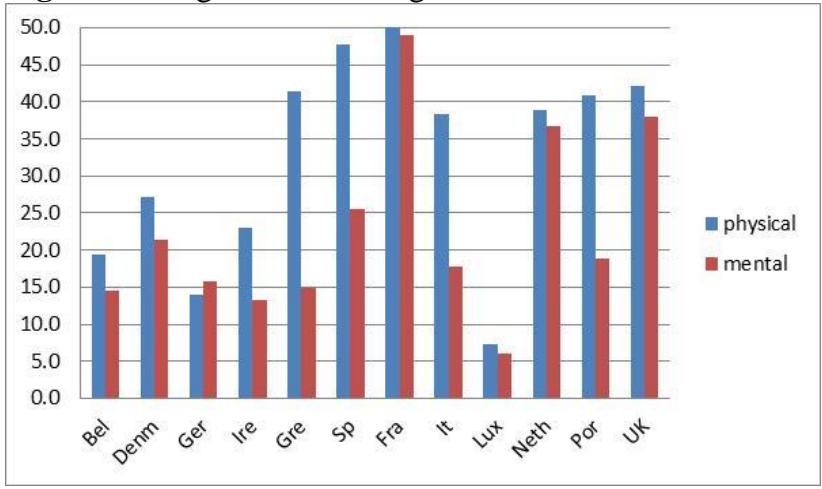

OECD (2014) devotes a long chapter to the assessment of job quality, where three dimensions are distinguished: earnings quality, labor market security and quality of the work environment. Two interesting findings are that "across countries it does not appear to be the case that better job quality is achieved at the cost of fewer jobs. Countries that perform well in terms of overall job quality also tend to perform well on job quantity (as measured by the employment rate), and vice versa" (81). [...] "The worst off are youth and lowskilled workers. They cumulate poor performance in terms of employment rates with poor outcomes along all three dimensions of job quality. [...] Temporary employment contracts are associated with lower job quality in all three dimensions" (81-82).

Looking at the GIISP countries compared to the EU12 we derive from the OECD findings that Spain, Greece, Ireland and Italy have the highest job insecurity (OECD, 2014, Figure 3.5), Greece, Spain, Portugal (France) and Italy have the highest job strain (ibid., Figure 3.8) and, assuming a medium inequality aversion, Portugal, Spain, Greece (Austria) and Italy have the low- 
est earnings quality (ibid., Figure 3.2B). Hence most GIISP countries have a remarkably high level of job insecurity and job strain and a remarkable low earnings quality.

\section{Active Inclusion and the Return to Full Employment}

It is important to understand how the welfare state in most European countries has developed in order to appreciate the emergence of the notion of inclusive labor markets and the potential role of job guarantee experiments therein. For that reason we briefly sketch in section 3.1 how the focus of the welfare state shifted from "full employment" in the first decades after WWII towards "full employability" since the mid-1980s. In section 3.2 we then argue that the notion of inclusive labor markets is on the one hand firmly rooted in the tradition of full employability, but also contains elements of a possible return to full employment. Finally we present in section 3.3 the job guarantee scheme as a possibility to enhance inclusive labor markets with a stronger emphasis on full employment.

\subsection{The shift from "full employment" to "full employability"10}

In Figure 13 we reproduce the Full Employment framework developed in Mitchell and Muysken (2008). It represents how the welfare state in most European countries in the decades after WWII was based on three main pillars. The Economic Pillar was defined by a serious commitment to full employment, which after the oil crises became blurred in the debate about the trade-off between inflation and unemployment. The Redistributive Pillar was designed to amend market outcomes, motivating equity intervention by governments in the form of income support and wage setting norms. The Collective Pillar provided the philosophical underpinning for the Full Employment framework, based on the intrinsic rights of citizenship and on solidarity.

Mitchell and Muysken (2008) discuss at great length how the reforms initiated in the Reagan-Thatcher era in the mid-1980s had serious implications for social policies all over Europe and led to labor market reforms as advocated by the OECD's "Jobs Study" (OECD, 1994). Mitchell and Muysken (2010) claim that, in the spirit of these reforms, the only way to resolve the pressures on the Redistributive Pillar was to reduce the public commitment to income support and the pursuit of equity. This shift in focus required a major recasting of the concept of citizenship which underpinned the Collective Pillar and had been an essential part of the rationale for the system of social security in the post-war period. Eventually, this development resulted in a shift from the "Full Employment" framework to the "Full Employability" framework - the latter is represented in Figure 14. 
Figure 13 The Pillars of the Full Employment framework

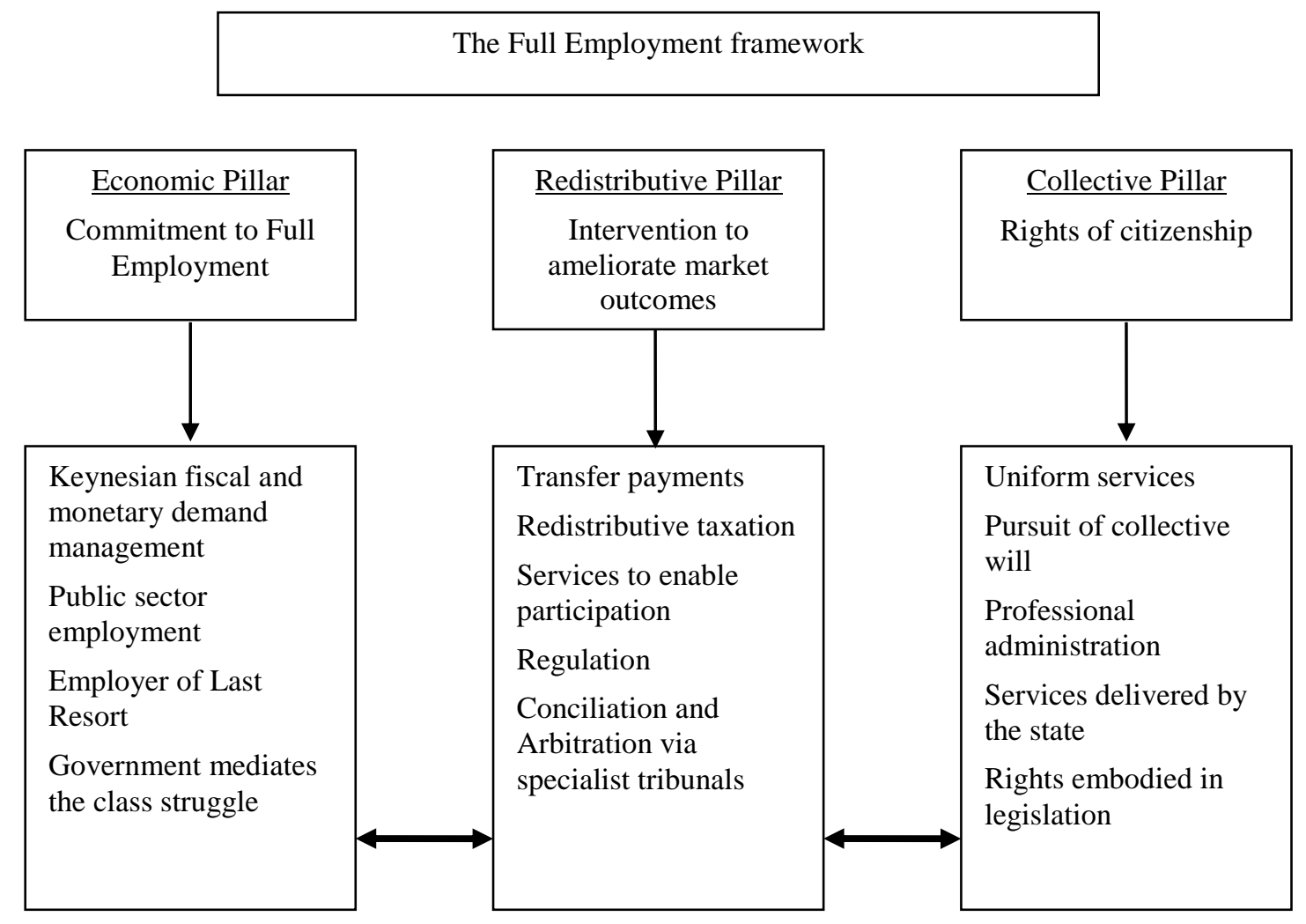

Source: Mitchell and Muysken (2008: Figure 1.1). 
Figure 14 The Full Employability framework

The Full Employability framework

\begin{tabular}{|c|c|c|}
\hline $\begin{array}{c}\text { Economic Pillar } \\
\text { Market-based } \\
\text { economic outcomes }\end{array}$ & $\begin{array}{c}\text { Redistributive Pillar } \\
\text { Intervention to } \\
\text { ameliorate market } \\
\text { outcomes }\end{array}$ & $\begin{array}{c}\text { Individuality Pillar } \\
\begin{array}{c}\text { No intrinsic rights of } \\
\text { citizenship }\end{array}\end{array}$ \\
\hline & $\downarrow$ & \\
\hline $\begin{array}{l}\text { Inflation targeting } \\
\text { Fiscal drag } \\
\text { Full employability and } \\
\text { compliance programs } \\
\text { (Workfare) } \\
\text { Government as an } \\
\text { agent for business }\end{array}$ & $\begin{array}{l}\text { Compliance tests and } \\
\text { penalties mediating } \\
\text { transfer payments } \\
\text { Taxation advantages } \\
\text { for high incomes } \\
\text { Policies to force } \\
\text { participation } \\
\text { Deregulation } \\
\text { Welfare-to-Work }\end{array}$ & $\begin{array}{l}\text { Non-uniform services } \\
\text { Individuals } \\
\text { responsible for their } \\
\text { own outcomes } \\
\text { Mutual/reciprocal } \\
\text { obligation } \\
\text { Outsourcing of public } \\
\text { services } \\
\text { Privatized service } \\
\text { delivery }\end{array}$ \\
\hline
\end{tabular}

Source: Mitchell and Muysken (2008: Figure 1.3). 
Under the "Full employability" framework collective will has been usurped by the primacy of the individual. Unemployment is seen as a problem of welfare dependence rather than a deficiency of jobs. As a consequence individuals now face broader obligations: they have to accept responsibility, be selfreliant, and fulfill their obligations to society. In many countries reciprocal obligation was developed as a leading principle, aiming at reintegration in the labor market. That is the receipt of benefits is contingent on meeting behavioral criteria and providing services community - often in an almost punitive, disciplinary context.

There are two major shortcomings in the full employability framework. First, the asymmetry in the reciprocal obligation is that the government does not have the obligation to ensure that there are enough jobs for all those wanting work. Second, the impact of macroeconomic circumstances on unemployment is not recognized: In times of a shortage of aggregate demand aggregate unemployment is inevitable. These shortcomings are modified by the introduction of the concept of inclusive labor markets as we argue below.

\subsection{Inclusive labor market policies}

The concept of inclusive labor markets was introduced as one of the strands of the EU Commission Recommendation of 3 October 2008 on the active inclusion of people excluded from the labor market. The Recommendation advocated an integrated active inclusion strategy based on three pillars: adequate income support, access to quality (social) services and inclusive labor markets. Member States were encouraged to develop and implement comprehensive policies built around the mutually reinforcing roles of each of the three strands. This approach gained gradual acceptance as a key reference point of the EU's current approach towards combating poverty and social exclusion, which has been embedded in the inclusive growth pillar of the Europe 2020 strategy (Frazer and Marlier, 2010; Klosse, 2013; Natali, 2014).

In the light of the discussion in the previous section, it is interesting to read carefully the following statement, derived from the EU Commission Recommendation on active inclusion:

The persistence of poverty and joblessness and the growing complexities of multiple disadvantages call for comprehensive, integrated policies. With a view to modernizing social protection systems, adequate income support needs to be combined with a link to the labor market and access to quality services in an integrated active inclusion strategy. This strategy is fully complementary to the flexicurity approach, while targeting those excluded from the labor market. It contributes to the Lisbon strategy by facilitating the activation and the mobility of the workforce, and represents a building block in the social dimension of the EU's sustainable development strategy. 
This statement reveals the ambivalent character of the active inclusion concept (Marlier and Natali, 2008). On the one hand, the Recommendation recognizes (a) the persistence of poverty and joblessness (although it does not link this to macroeconomic failures) and (b) the need of adequate income support and a link to the social dimension of the EU's sustainable growth strategy. Both can be seen as steps towards the full employment framework. However, on the other hand, (c) the reference to the flexicurity approach and (d) the focus on activation and mobility of the workforce seem more in line with the full employability framework. This ambiguity is in line with the observation by Marchal and Van Mechelen (2015) that the Recommendation "aims to connect activation recipes to enhanced social protection and the broader set of welfare provisions aimed at social inclusion" (5). ${ }^{11}$

The evaluation by Marchal and Van Mechelen on active inclusion in European minimum income schemes provides some further insights. They take the three pillars which constitute active inclusion policies, i.e. adequate income support, inclusive labor markets and access to affordable and quality services as point of departure for their analysis. They show how these three pillars can be used as a classification scheme in order to assess the variation in activation strategies pursued in EU member states. However, they argue that the inclusive activation strategy has two dimensions, which should be explicitly distinguished. The first dimension has a focus on incentives to enhance participation in the labor market (with a strong focus on stimuli to lower the reservation wage). The second dimension emphasizes human capital formation (with a strong focus on education and vocational training). "It favors improving individual capacities, rather than inducing behavioral change" (Marchal and Van Mechelen, 2015: 4). Together these distinctions then amount to four aspects of social inclusion, summarized in the column headings of Table 1.

Their general findings on each of the four aspects of active inclusion for 20 countries are that most countries do not provide adequate income support. Also the provision of affordable services is not sufficient. This is consistent with our earlier observation of the shift away from the Full Employment Framework in the direction of the Full Employability Framework. The latter is also reflected in the more directly labor market related aspects of active inclusion. All countries show at least some adherence to the inclusive labor markets pillars, and generally, substantially so. Especially in the incentives sphere, most countries reach high membership scores, whereas membership scores in the enabling dimension are less outspoken (Marchal and Van Mechelen, 2015: 14). These findings are reflected in Table 1 for the countries of the EU12 which Marchal and Van Mechelen studied. ${ }^{12}$ 
Table 1 Scores on active inclusion labor market policies

$\begin{array}{lllll} & \text { Adequate income } & \text { Enabling } & \text { Incentives } & \text { Services } \\ \text { BE } & 0,20 & 0,75 & 0,84 & 0,82 \\ \text { DE } & 0,26 & 0,75 & 0,57 & 0,43 \\ \text { FI } & 0,38 & 0,87 & 0,34 & 0,55 \\ \text { FR } & 0,00 & 0,75 & 1,00 & 0,13 \\ \text { IT } & 0,00 & 0,50 & 1,00 & 0,45 \\ \text { LU } & 0,51 & 0,75 & 0,84 & 0,27 \\ \text { NL } & 0,81 & 0,50 & 0,67 & 0,36 \\ \text { PT } & 0,00 & 0,47 & 0,97 & 0,00 \\ \text { UK } & 0,39 & 0,50 & 1,00 & 0,00\end{array}$

Source: Marchal and Van Mechelen (2014: Table 7).

Similar observations have been made in the evaluation of national policies on active inclusion by Frazer and Marlier (2013). They observe that, while there has been progress in some Member States, this is often uneven and partial. The effective implementation of the Recommendation across the EU is still far away. However, some progress has been made in designing and implementing active inclusion measures for those who can work than for those who cannot work. "As the impact of the economic and financial crisis has deepened and as an increased emphasis has been put on financial consolidation and austerity measures, resources have become tighter and the approach has tended to become (even) more unbalanced. A significant factor in many countries which has limited the implementation of an active inclusion approach has been the introduction of austerity measures in response to the economic and financial crisis" (Frazer and Marlier, 2013: 7 - see also Crepaldi et al., 2015).

\subsection{The notion of a Job Guarantee}

The previous sections 2.2 and 2.3 revealed the failure of the active inclusion policies to realize inclusive labor markets. In this section we present the idea of a job guarantee as an alternative route forward. The idea of a job guarantee stems from a long tradition in the USA. It was advocated by institutionalists, such as Copeland, Gordon and Minsky. In particular the latter introduced the role of the government as employer of last resort (ELR) - see Minsky (1965). This was taken up by Wray (1998) and has led to active groups based at the University of Missouri-Kansas City (Forstater, 1999; Tcherneva, 2005; Fullwiler, 2007) and at the Levy institute (Kregel, 2009; Godin, 2013; Papadimitriou et al., 2016) elaborating on ELR-policies. Around the same time Mitchell (1998) introduced the notion of a job guarantee in Australia. Bill Mitchell established a group in the Centre of Full Employment and Equity (CofFEE) at the University of Newcastle in Australia which is actively advocating and developing Job Guarantee schemes (Quirk et al., 2006; Coffee, 
2008; Watts, 2010; Juniper et al., 2014). All these groups are now cooperating closely and have been joined by CofFEE-Europe based in Maastricht University, which amongst others inspired the present paper (see also Mitchell and Muysken, 2008; 2010). Without acknowledging links to these groups Atkinson (2015) has also embraced the ELR concept and proposed detailed plans to introduce ELR in Britain and in Europe. ${ }^{13}$ Finally, there have been various debates on the potential problems with introducing a JG-scheme see for instance Aspromourgos (2000), King (2001), Palley (2001), Sawyer (2003; 2005) and Mitchell and Wray (2005) for a general debate and see Standing (2005; 2013), Noguchi (2013), Harvey (2005; 2013), Tcherneva and Wray (2005) and Tcherneva (2013) for a discussion in relation to basic income.

We briefly summarize the main aspects of the Job Guarantee Scheme below, drawing heavily on Mitchell and Muysken $(2008$; 2010) to which we also refer for more details. The aim of the JG-scheme is to ban involuntary unemployment. For that reason the government ensures the availability of suitable public sector jobs at the statutory minimum wage level for anyone willing and able to work. In this way the scheme supports continuity of income and labor force attachment, without recourse to social welfare dependence. So instead of wielding a stick to force those on social welfare benefits to accept in many cases low quality work, it provides a carrot in the form of quality jobs. The scheme also provides appropriately structured training activities on the job. As such, a properly designed Job Guarantee scheme can help previously unemployed persons to make transitions into careers in the private sector and also stimulate employers to modify their recruitment behavior.

A Job Guarantee Scheme can also help to solve the problem of timerelated underemployment as it provides the opportunity for under-employed workers to engage in full time employment. In turn, this could place pressure on private sector employers, who have failed to provide sufficient hours of work to satisfy the preferences of their workforces, to restructure their workplaces so as to overcome the discontent that their underemployed workers feel.

As Mitchell and Muysken (2008) emphasize, the Job Guarantee idea is firmly embedded in the notion of full employment, which recognizes the basic right of every individual to "just and favorable conditions of work" as expressed in the 1948 Declaration of Human Rights and in the European Social Charter. It is also consistent with the notions of social cohesion, social inclusion and human dignity which are listed among the key values and aims of the EU (articles 2 and 3 Treaty of the European Union (TEU). The Job Guarantee idea should therefore be distinguished from proposals for a basic income. The problem with basic income is that societies do not automatically feel responsible for the wellbeing of persons they provide a basic income to. This might pose a threat to social cohesion. The basic income does not impose any responsibility on the individuals either and hence also might threaten human dignity. A more elaborate discussion, including macroeconomic con- 
siderations, is provided in Mitchell and Watts (2004) - see also the references given above.

Finally, as we elaborate below, using the job guarantee for the provision of collective goods and services might revive the public awareness of their importance and lead to a normal provision of these jobs. In that context, as is stressed in Mitchell and Muysken (2010), an appropriate Job Guarantee Scheme also acknowledges the strains on our natural ecosystems and the need to change the composition of final output towards environmentally sustainable activities. Environmental projects are ideal targets for public sector employment initiatives as they are likely to be under-produced by the private sector due to their heavy public good component. If a portion of Job Guarantee jobs were used to repair and restore the environment, the workers would re-gain personal dignity, and society would gain from the increased provision of goods and services which support sustainability. It is not increased demand per se that is necessary but increased demand in sustainable areas of activity.

From a macroeconomic perspective it is important to note that the JG-job will be paid according to the mandatory minimum wage, thus keeping the earnings below the prevailing wage on the labor market. ${ }^{14}$ The Job Guarantee acts as a job buffer, ensuring that there is full employment over the business cycle, while inflation is being kept under control. The Job Guarantee does not raise inflation even though there is no (involuntary) unemployment because the wage of the JG is below the market clearing wage. If there would be any inflationary pressure, the government could easily suppress this by tightening its fiscal and/or monetary policy. Since the non-accelerating inflation rate of the unemployment rate under a Job Guarantee Scheme would be much lower than the "ordinary" NAIRU, it would result in much less wastage of labor resources. All these arguments are elaborated in Mitchell and Muysken (2008). We discuss the financing of the JG in the next section, where we also discuss the various objections that have been raised in the discussions referred to above.

\section{Experiments with Job Guarantee Policies}

The overview of European labor markets in section 2 did show a gradual deterioration of job quality and an increase in work-in poverty, which we associated in section 3.2 with the shift from "full employment" to "full employability." The strong rise of unemployment after the financial crisis also exposed the lack of awareness of the full employability policies for macroeconomic market failures. We argued in section 3.2 that inclusive labor market policies are a step in the right direction. However, we also observed that, due to the austerity measures implied by the financial crisis, the implementation of these policies stagnated. Moreover, the macroeconomic problem of deficient 
demand still has to be tackled. The introduction of a Job Guarantee Scheme could help to solve both problems. It can generate both sustainable employment in good quality jobs and an adequate income, and it tackles the problem of deficient demand by stimulating the economy. One might wonder, however, whether this will really work out in this way in practice and how such a scheme should be implemented. These issues will be discussed below. We first summarize earlier experiences with Job Guarantee Schemes in section 4.1. Then we elaborate on the implementation of Job Guarantee experiments in section 4.2, where we also discuss how one might deal with the problems raised in earlier discussions. In section 4.3 we discuss the financial implications.

\subsection{Earlier experiences with the Job Guarantee Scheme}

There have been some rather successful field experiments with the Job Guarantee Scheme in Argentine, South-Africa and India - see Mitchell and Muysken (2008, Ch. 9.6) for an overview. An interesting example is the Plan Jefes which was implemented in Argentina as a depression solution after the crisis in 2001. The Plan did run until 2008.

Characteristic of the Plan Jefes was that it took workers "as they are." Jobs were provided to heads of households (presumably male), but the intrahousehold decisions in the majority of cases designated the woman as the head of the household. In 2005, almost $75 \%$ of the participants who turned up for work were women. There were no skills means tests and men and women were offered employment into community projects irrespective of their past labor market experience, level of education, or skills. The government had estimated that 500,000 persons would show up for work, whereas, at its peak, Jefes had hired 2 million persons (Tcherneva, 2012: 8).

As Tcherneva shows, Plan Jefes provided the predicted macroeconomic stabilization effects and established a wage floor for those workers who transitioned from the Jefes program to private sector work. Not surprisingly almost $93 \%$ of Jefes workers who were hired into private firms were offered a wage above the Jefes wage. The majority of Jefes projects provided useful community work. In some cases, the projects literally transformed communities.

Projects included improvements in the water supply, sewer systems, and pluvial networks. They made investments in health and educational infrastructure, improved hydraulic defenses, clay pits, municipal slaughter houses, recreational and tourist areas, and many others. In many instances, Jefes funds were used as seed money by the unemployed to launch their own businesses and microenterprises, some of which made toys from recyclable materials, others manufactured clothing for the domestic or export market or set up carpentry and other artisanal shops (Tcherneva, 2012: 14). 
In India, the National Rural Employment Guarantee Scheme (NREGA) started in 2005. It entitles every rural household in India to a minimum of 100 days of paid work per year. This is an unrestricted entitlement with no eligibility requirements. Employment in the scheme increased, spreading out over rural areas, from 21 million households in 2006-07 to 33.9 million households in 2007-08 and 53 million households in 2010-11. Anzar (2012) finds that NREGA has a positive impact on the labor force participation, mainly driven by increased female participation. He also finds a significant positive impact on the wages of female casual workers - real wages of $8 \%$, and a modest impact on wages of casual male workers of $1 \%$. Other positive evaluations are provided by Deininger and Liu (2013) and Imbert and Papp (2015). The experiments in India have expanded over time and still continue with success.

We are not aware of Job Guarantee experiments in Western economies. A Dutch program most closely resembling the job-guarantee was the Melkertjobs program started in 1994. On an annual basis 40 to 60 thousand additional public sector jobs were created, paid by the government. This program was one of the few activation programs that aimed "at participation in a wider sense than labor-market integration only." 15 (van Berkel and de Schampeleire, 2001: 33). Although its name changed to "ID-Jobs" in 1999, this program essentially ran from 1994 until it was cancelled in 2004 - see also Stiller and van Gerven (2012). An interesting aspect of the Melkert jobs was that they generated many collective services which were canceled due to austerity measures. The cancellation of these jobs then led to a deterioration in these services which was generally felt as a loss. This latter point is clearly recognized by Atkinson (2015, Ch. 5): JG jobs create genuinely valuable output and should not be evaluated solely on the subsequent labor market success of participants.

Two examples of mistaken interpretations of the JG approach are the "Job Guarantee" proposed in Layard (2009) and the "EU Youth Guarantee Scheme" launched in 2013 (EU, 2012). The first scheme only provides temporary solutions for long-term unemployed young persons. The second scheme seeks to reduce the risk of long-term unemployment amongst young people by inducing the Member States to ensure that all young people under 25 - whether registered with employment services or not - receive a concrete and goodquality offer for a job, apprenticeship, traineeship, or continued education within 4 months after leaving formal education or becoming unemployed. It is too early to evaluate the success of the scheme, but the first indications are not very positive due to a serious lack of funding and jobs of sufficient quality as reported by both the European Court of Auditors (2015) and Escuardo and Morello (2015). "The overwhelming problem with the Youth Guarantee proposal is that it skirts around the main issue, a lack of jobs. It continues the emphasis on full employability .... What is needed in Europe 
is a large scale job creation program for those who are not in formal education or formal apprenticeship programs" (Mitchell, 2015: 440).

\subsection{Implementing job guarantee experiments}

One should always adhere to the spirit of full employment - see section 3.1 above - when implementing a Job Guarantee Scheme. That is, one should aim at sustainable employment in quality jobs, in line with personal capacities and not stigmatizing individuals or groups. A detailed proposal of how to implement a JG scheme within the Australian context has been developed in Quirk et al. (2006) and CofFEE (2008: Ch. 13) - see also Atkinson (2015: Ch. 8) for a proposal consistent with the British situation. Both proposals rely heavily on the existing administrative structure and imply a relatively large bureaucracy. That may be a drawback of the JG scheme which is inevitable (Noguchi, 2013; Standing, 2013), although this bureaucracy is also present in the current social benefits system.

For that reason we also encourage local initiatives and exchange of experiences - see also Klosse and Muysken (2014). This means that within a country each municipality or neighborhood and each individual could come up with a concrete proposal for work under the Job Guarantee Scheme. ${ }^{16}$ Each reasonable proposal should be tried out, within limits, and terminated when it turns out to be a failure. Thus, one can learn from both the successes and the failures of others. Successful experiments may then be implemented on a larger scale and learning from each other should be encouraged.

It is very well possible to involve the social partners (trade unions and employers) in the implementation of a Job Guarantee Scheme. It might thus become a public-private-partnership. ${ }^{17}$ There might also be a relationship with activities on the shop floor, such as training - see Gerards, Muysken and Welters (2012) for a successful experiment with a large company in the Netherlands. One should realize, however, that training and education are not a panacea for all evils. As long as there is a shortage of jobs, training is paramount to stirring a cup of tea. But training within a paid employment context, created by the Job Guarantee Scheme or other forms of sustainable employment, helps to overcome churning unemployed through the current active labor market policies: there always has to be the prospect of a job after training. In that context, it is important to involve employers in the Scheme, since they can contribute strongly to creating trainee posts. Also the employers should realize that training on the job will strengthen the motivation of the worker and will probably yield a higher return (Voegtlin et al., 2015). Initial good matching is an essential ingredient in that respect (Maguire, 2015). Vital is furthermore that employers are encouraged to create suitable employment opportunities for vulnerable groups, using concepts like "job crafting" and, more in particular "tasks differentiation" (Van der Klink et al., 2014; 
Parker, 2014). Finally, ageing of the population also emphasizes the significance of sustainable employment (Cloostermans et al., 2015).

A relevant question is crowding out of private and public sector jobs (Sawyer, 2005; Noguchi, 2013). There are four aspects to this. First of all it is very hard to argue whether crowding out takes place or not. One could argue that when there is no vacancy for a certain job, employing a person in JG-job to do the relevant work implies no crowding out - an example would be a janitor at a primary school which has neither a janitor nor a vacancy for that position. This criterion is often used in the Netherlands (Klosse and Muysken, 2014). One can object to this criterion that previously existing jobs then might be terminated and replaced by relatively cheap JG-employees without posting a formal vacancy. This is indeed a problem that should be recognized and requires careful monitoring, also with help of social partners - see also CofFEE (2008: Ch. 13) and Atkinson (2015: Ch. 8) for more detailed proposals.

Second, implicit in many JG-proposals is the notion that as is explicitly discussed in Noguchi (2013) there is a general lack of public goods and services nowadays, which can very well be provided by JG-jobs. However, if the cycle goes up persons employed in these "indispensable" JG-jobs are drawn into the private market, which leaves an irreplaceable void (Sawyer, 2004). Mitchell and Wray (2004) argue that there can be a hard core of deficient aggregate demand which then can be use to fill these jobs, but that is not very clear. One might hope that the provision of these goods and services revives the public awareness of their importance and leads to a normal provision of these jobs (Noguchi, 2013; Atkinson, 2015).

Third, one should realize that some alleged crowding out is part of labor market dynamics. For instance, Imbert and Papp (2015) show that in India's rural areas part of the JG-jobs crowd out private sector jobs, leading to an increase of the private sector wage. They show that this increases overall welfare.

Fourth, some private sector jobs might offer such unfavorable conditions that employees will prefer to work in JG-jobs. In that case the Job Guarantee provides a minimum standard for job quality which should be recognized as worthwhile and forces private employers to obey that standard (Mitchell and Wray, 2004; Mitchell, 2015).

\subsection{How to finance job guarantee experiments}

A final question is how to finance job guarantee experiments. In Mitchell and Muysken (2008) it is explained that from a macroeconomic perspective there should be no objection to finance Job Guarantee policies by issuing money by the Central Bank. This is has always been highly controversial and branded JG proposals as completely unrealistic. 
However, central bank funding is not necessary to start experimenting with Job Guarantee initiatives as the experiments described in section 4.1 have shown. A lot of funds spent on social benefits and the administration system can be redirected to Job Guarantee projects (CofFEE, 2008: Ch. 13; Atkinson, 2015: Ch. 8). Next to that, the European Commission has recently launched "An investment plan for Europe" in which it proposes to invest at least EUR 315 billion in the European economy by $2017 .{ }^{18}$ This plan, also known as the "Juncker plan," can very well be used to incorporate JG-jobs for instance by requiring that $5 \%$ of each investment is spent on employing persons belonging to vulnerable groups (Social Return).

Moreover, one should realize that the ECB is currently injecting $€ 80$ billion in the Euro Area each month (amounting to over 8\% of GDP on an annual basis) and recently has extended that $\mathrm{QE}$ program. This measure has been strongly criticized for many reasons, but we focus here on the argument that by providing the injection through bond purchasing programs, there is a threat of a new asset bubble of which only the already wealthy persons will profit. This objection inspired Muellbauer (2014) to propose that the ECB hands out a check to every euro area citizen in stead of buying bonds - that would have better distributional consequences in his view. We share Muellbauer's objection, but think that handing out a cheque to every euro area citizen also has questionable distributional consequences. Using (part of) this money to finance Job Guarantee projects would be in line with the macroeconomic analysis in Mitchell and Muysken (2008) and would directly stimulate the economy in the strongest possible way. It could also provide additional capacity to the large investment plan of the European Commission. The latter is in line with the proposal of the Grauwe (2016) who argues that "while QE was and is necessary, it is insufficient. It has to be seconded by fiscal policies, ..., it is precisely public investment that is key to the recovery in the euro zone. ... our grandchildren will ask us why we did not invest in alternative energy and public transportation, and thereby made their lives miserable, when we faced historically favorable financial conditions to do so." 19

\section{Concluding Remarks}

From our analysis of the European labor market we learned that there is a clear scope for improvement in activity rates when comparing different countries, although one should recognize the variation in underlying reasons for inactivity when proposing improvements for different countries. This implies a distinct role for active inclusion policies. However, these policies should be complemented by stimulating macroeconomic policies since there has been a strong increase in unemployment, in particular in the GIISP 
countries, due to a fall in aggregate demand. This problem is exacerbated by the observation that there is probably an interaction between inactivity and unemployment, leading to hidden unemployment.

Active inclusion policies are also warranted by the observation that sustainable employment is impeded by the pervasiveness of temporary work, self-employment and part-time work. The incidence of temporary work and part time work has increased systematically and is often accepted due to a lack of better jobs. Although self-employment is relatively stable at $15 \%$ of total employment, the vulnerable group of own-account workers amongst them has increased. Moreover the share of "work at risk of poverty" jobs has increased, in particular amongst foreigners, low educated persons and youngsters - who also have a high incidence of inactivity and unemployment. Finally most GIISP countries have a remarkably high level of job insecurity and job strain and a remarkable low earnings quality.

Against this background we deplore that the implementation of active inclusion policies, initiated in 2008, never really took off and stagnated due to the austerity measures enforced after the financial crisis. For that reason we propose to experiment with job guarantee $(\mathrm{JG})$ projects, which on the one hand should provide a macroeconomic stimulus to the economy by employing everybody who is out of work in Job Guarantee jobs at the minimum wage. On the other hand by providing quality jobs and sustainable employment, also encouraging local initiatives, the downward trend in job quality observed by the OECD Employment Outlook can be stopped and inclusive labor markets will be fostered. We propose for that reason to finance the Job Guarantee Scheme by redirecting social security (administration) funds, by including Job Guarantee elements in the European Investment Plan (also known as the Juncker Plan) and to spend part of the $€ 80$ billion which the ECB is currently injecting each month in the euro area on job guarantee projects.

We should keep in mind the finding of OECD that "across countries it does not appear to be the case that better job quality is achieved at the cost of fewer jobs. Countries that perform well in terms of overall job quality also tend to perform well on job quantity (as measured by the employment rate), and vice versa" (OECD, 2014: 32) ${ }^{20}$ This should be an additional stimulus to experiment with job guarantee projects. 
Appendix A1 Labour force participation in the EU15
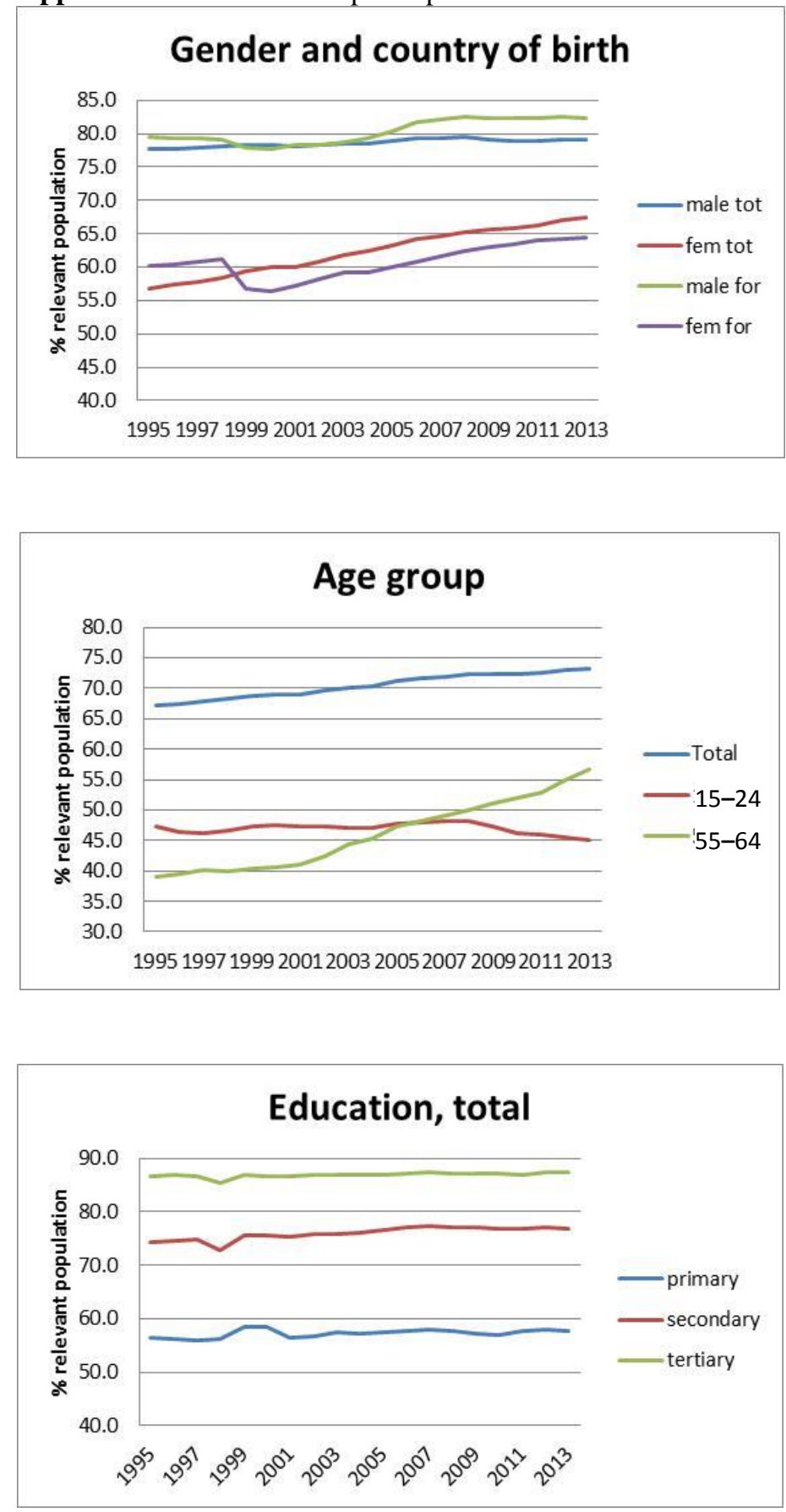


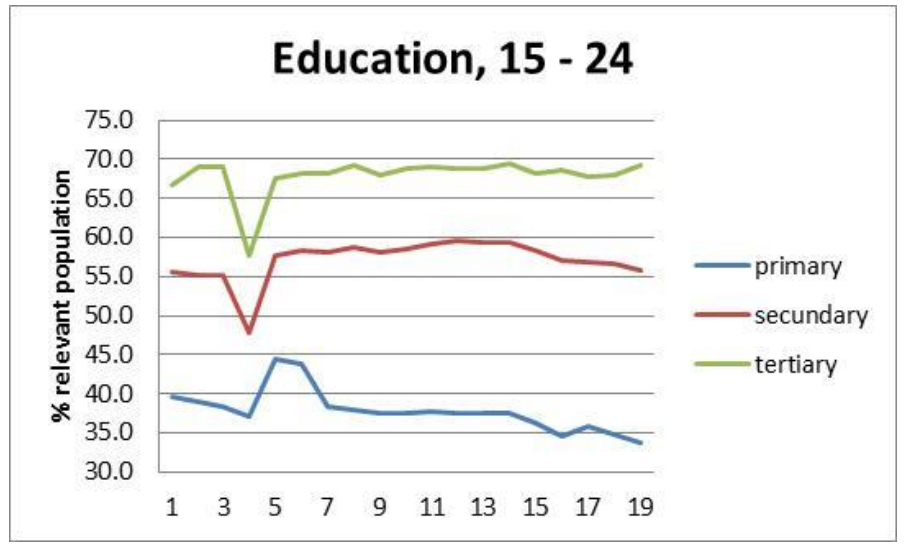

Appendix A2 Reasons for inactivity by country (EU12) ${ }^{21}$
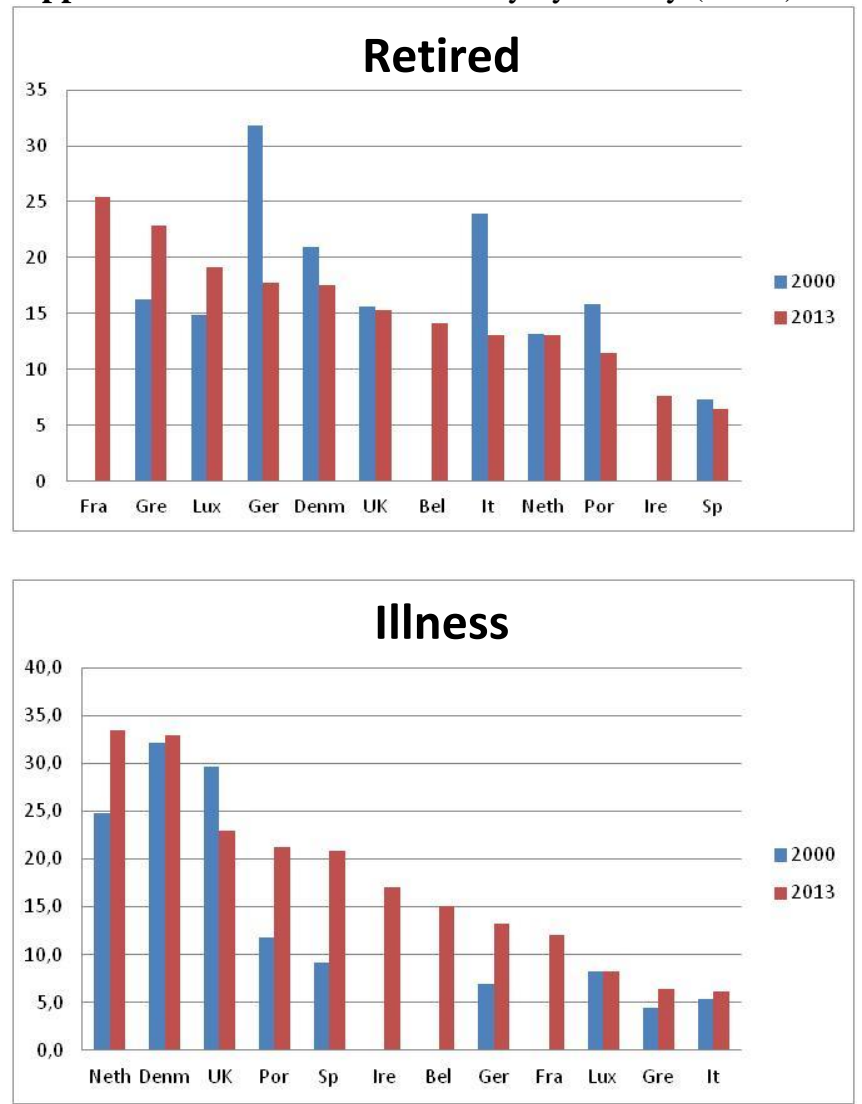

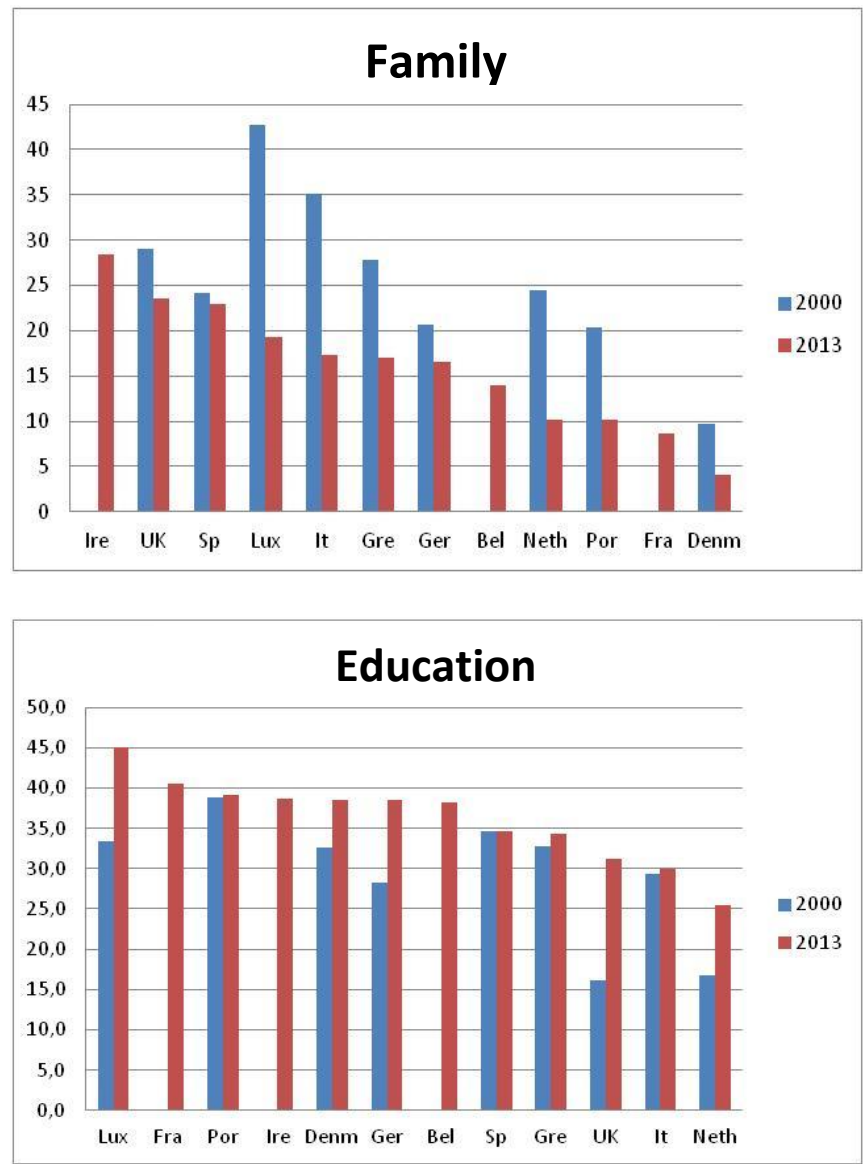

Appendix B Characteristics of unemployed in EU15 and wage share

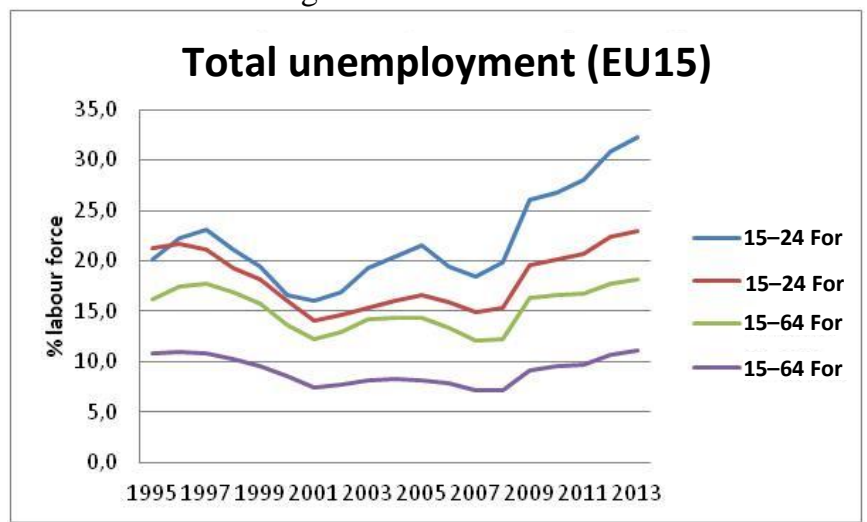



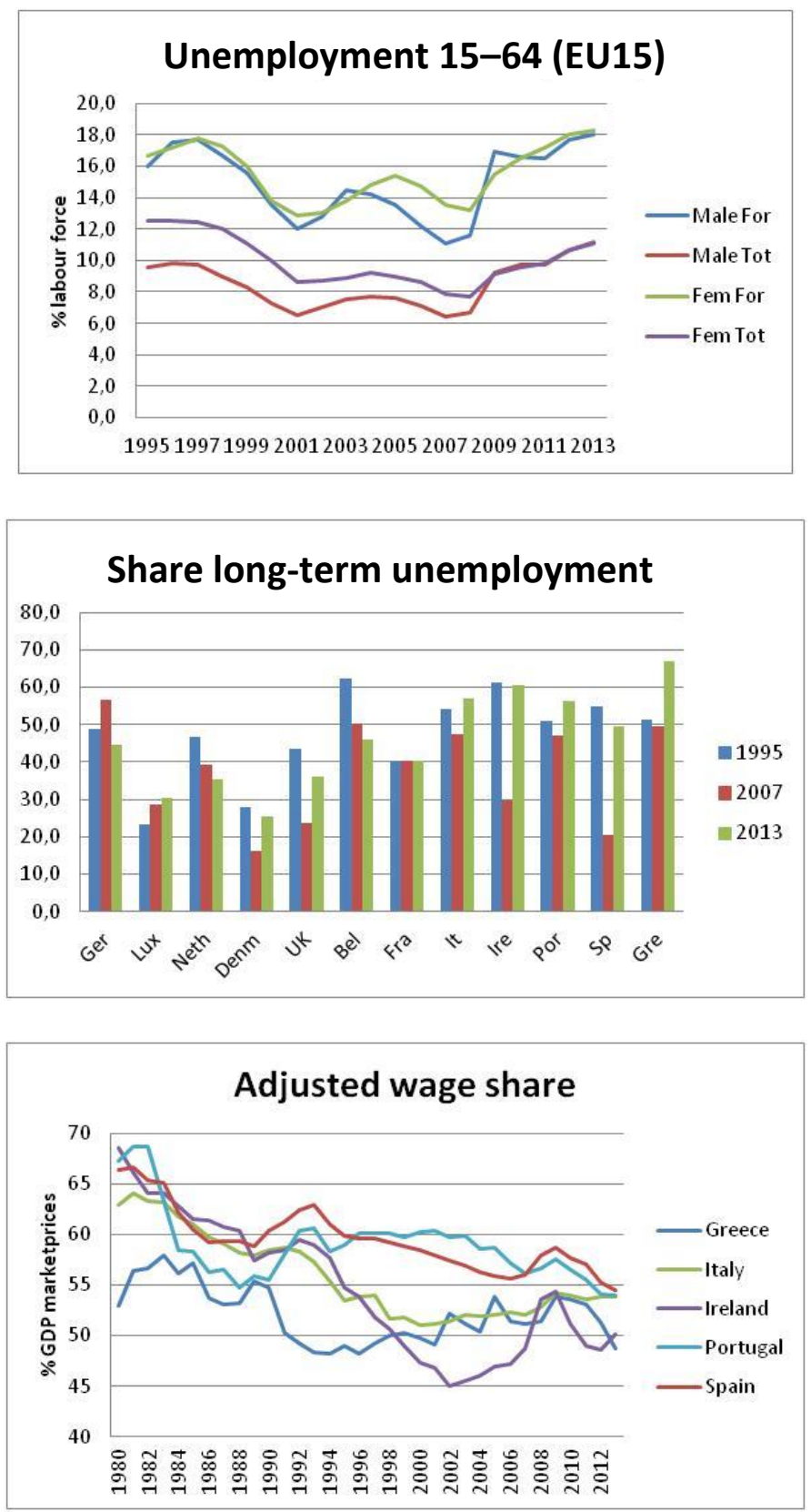
Appendix C
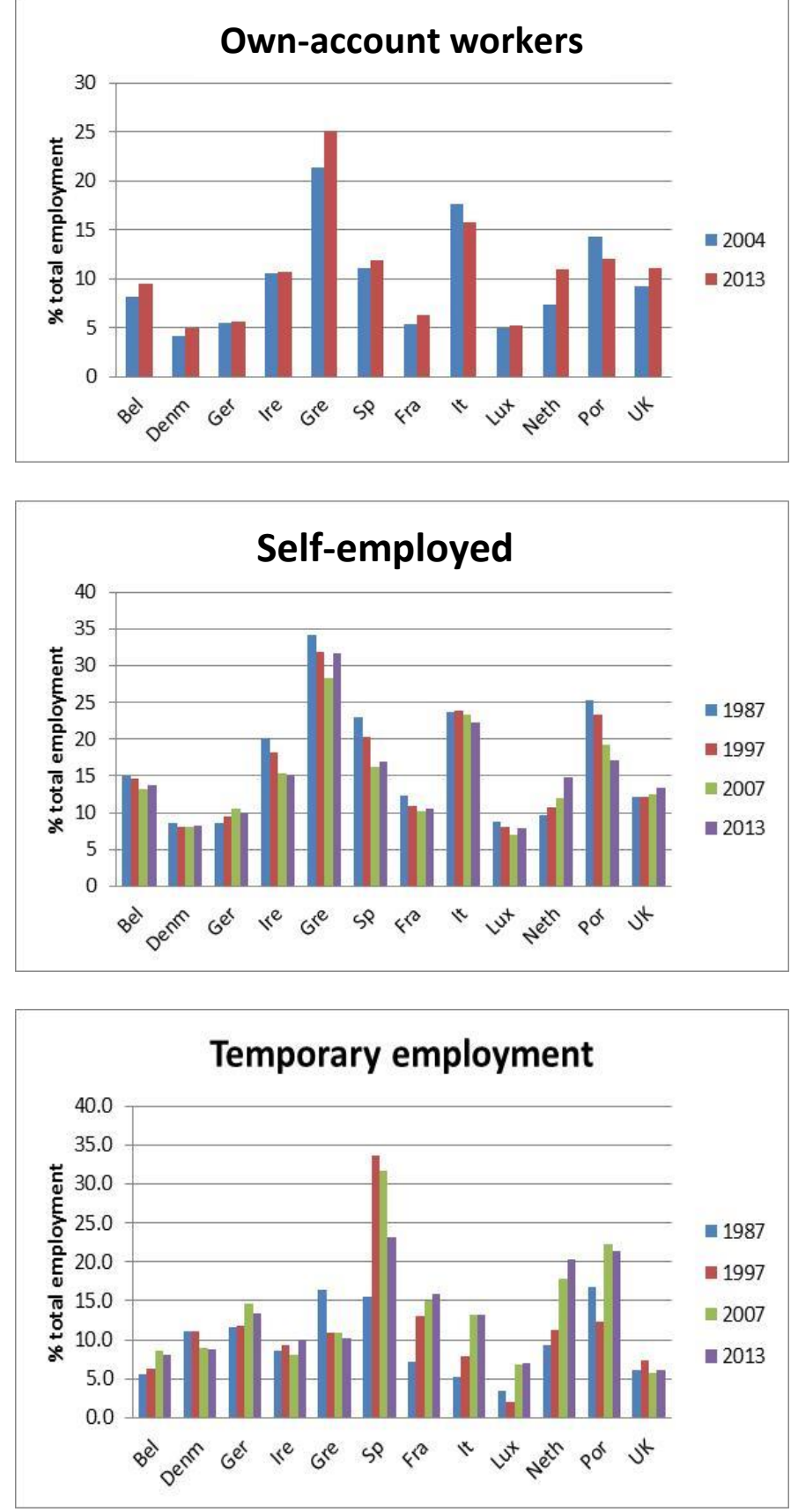


\section{Acknowledgements}

We would like to thank Riccardo Welters, unknown referees and the participants of the economics seminars at the University of Würzburg and at the IAB, Nüremberg for their critical comments. J. Muysken thanks Caritas-Europe for financial support with the project.

\section{NOTES}

1. Retrieved from the definition of inclusive labor markets on the EU web site: http://ec.europa.eu/social/main.jsp?catId=1134\&langId=en

2. The EU12 consists of Belgium, Denmark, France, Germany, Greece, Ireland, Italy, Luxembourg, the Netherlands, Portugal, Spain, and the United Kingdom. The EU15 also includes Austria, Finland, and Sweden. The data used in this section are taken from Eurostat.

3. These groups are "Less than primary, primary and lower secondary education (ISCED levels 0-2)" and "Upper secondary and post-secondary non-tertiary education (levels 3 and 4)," respectively.

4. A similar phenomenon is reported for long-term unemployment in Appendix B.

5. For instance OECD (2014: 21-22) claims "OECD estimates of the NAIRU (Non-accelerating inflation rate of unemployment) suggest that it has tended to increase since the start of the crisis in several OECD countries and particularly in Greece, Portugal and Spain." However, the OECD also recognizes that in most countries "Weak aggregate demand accounts for a significant part of the persistence of high unemployment." For a critical assessment of the OECD approach to the NAIRU we refer to Mitchell and Muysken (2008). We also show in Appendix B how the wage share in national income has decreased for the GIIPS countries till the financial crisis - except for the case of Greece, which has an exceptionally low wage share, however. The small upturn after the financial crisis in some countries is due to lagged adjustment of employment.

6. In this section we mainly refer to the OECD (2014) findings, since the OECD provides a comprehensive overview and can hardly be seen as a source which is biased in favor of emphasizing problematic labor market outcomes.

7. The notion that a probationary period leads to a permanent job is often mistaken as is indicated in OECD (2014, Ch. 4).

8. An interesting overview for several countries is presented in Eichhorst et al. (2013).

9. This threshold is set at $60 \%$ of the national median equivalized disposable income (after social transfers).

10. This section relies heavily on Mitchell and Muysken $(2008 ; 2010)$ - see also Judt (2010) and Atkinson (2015) for similar observations.

11. The same ambiguity is also visible in Guideline 10 of the Europe 2020 Integrated Guidelines on promoting social inclusion and combating poverty: COM 2010, 193 final. See Klosse (2013: 506).

12. In order to include one Scandinavian country, we included also Finland. 
13. Mitchell (2015, Ch. 23) also mentions the Job Guarantee scheme as a possible solution for the European problems, but he is quite pessimistic about the possibilities to implement it due to diverging political views.

14. The minimum wage should be such that a full time job at the minimum wage does not lead to in-work poverty.

15. The authors continue: "It involves promoting participation in unpaid activities such as voluntary or community work. This 'route' towards inclusion has hardly been developed in active social policies." A similar observation is made in Ochel (2005).

16. Some examples of possible activities are: (1) informal care for elderly people (e.g., transport, courses, helping with ICT); (2) refurbishing the neighborhood (e.g., playgrounds, green areas, a neighborhood platform); (3) designing and developing inner-city plans (banishing cars, reducing energy consumption). See CofFEE (2008) for an extensive list of activities, based on interviews with local community workers.

17. However, we are quite wary of PPP's since the partners often have asymmetric positions.

18. See Commission document COM (2014) 903 of 26.11.2014.

19. To be fair, de Grauwe (2016) definitely does not propose a JG-scheme and his implicit proposal for using the QE-program to finance public investments is confined to "countries, like Germany, France, Belgium and the Netherlands." There is a fierce discussion on the alleged financing of JG-programs by "printing money" between adepts of Modern Modern Theory (MMT) and its opponents - see Mitchell (2015, Ch. 21) for further references.

20. See also the observation by de Grauwe (2016): "European authorities have put great emphasis on structural reforms to boost long-term economic growth. Econometric analysis of the relation between long-term growth and structural reforms (see IMF, 2015, and De Grauwe \& Ji, 2015) suggests that these reforms have a weak effect on growth. These same studies, however, reveal that public and private investments are far more important to boost economic growth."

21. Main reason for not seeking employment: (1) Retired; (2) Own illness or disability; (3) Looking after children or incapacitated adults and other family or personal responsibilities; (4) In education or training.

\section{REFERENCES}

Aspromourgos, A. (2000), "Is an Employer-of-Last-Resort Policy Sustainable? A Review Article," Review of Political Economy 12(2): 141-155.

Atkinson, A.B. (2015), Inequality: What Can Be Done? Boston, MA: Harvard University Press.

Azam, M. (2012), "The Impact of Indian Job Guarantee Scheme on Labor Market Outcomes: Evidence from a Natural Experiment," IZA-Discussion Paper, No. 6548, Bonn.

Berkel van, R., and J. de Schampheleire (2010) "The Activation Approach in Dutch and Belgian Social Policies," Journal of European Area Studies 9(1): 27-42. 
CofFEE (2008), "Creating Effective Local Labour Markets: A New Framework for Regional Employment Policy," CofFEE Policy Report, Centre of Full Employment and Equity, The University of Newcastle, Australia.

Cloostermans, L., M. Bekkers, E. Uiters, and K. Proper (2015), "The Effectiveness of Interventions for Ageing Workers on (Early) Retirement, Work Ability and Productivity: A Systematic Review," International Archives of Occupational and Environmental Health 88: 521-532.

Crepaldi, C., M. Samek, A. Eydoux, A. Scheele, and I. Topinska (2015) "Active Inclusion: Stocktaking of the Council Recommendation" Study for the EMPL Committee, IP/A/EMPL/2015-05, PE 569.971, November, 8-63.

Christl, M., and D. Kucsera (2014) "Die Auswirkungen der konjunkturbedingten Erwerbstatigkeit auf die Arbeitslosenrate in Osterreich und der Europaischen Union," Wirtschaftspolitische Blatter 61(1): 225-250.

De Grauwe, P. (2016), "Monetary Policy and Public Investment," CEPS Commentary, 14 January.

De Grauwe, P., and Y. Ji (2015), "Has the Eurozone Become Less Fragile? Some Empirical Tests," Journal of Policy Modeling 37(3): 404-414.

Deininger, K., and Y. Liu (2013), "Welfare and Poverty Impacts of India's National Rural Employment Guarantee Scheme,” IFPRI Discussion Paper 01289.

Eichhorst, W. et al. (2013), "Social Protection Rights of Economically Dependent Self-employed Workers," IZA Discussion Paper, No. 54, Bonn.

EU (2012), Commission Staff Working Document SWD(2012) 409 of 18.4.2012.

Forstater, M. (1999), "Functional Finance and Full Employment: Lessons from Lerner for Today," Journal of Economic Issues 32(2): 475-482.

Frazer, H., and E. Marlier (2010) "The EU's Approach to Combating Poverty and Social Exclusion: Ensuring a Stronger Approach in the Future by Learning from the Strengths and Weaknesses of the Current Approach," Kurswechsel 3: 34-51.

Frazer, H., and E. Marlier (2013), "Assessment of the Implementation of the European Commission Recommendation on Active Inclusion: A Study of National Policies," CEPS/INSTEAD.

Fullwiler, S. T. (2007), "Macroeconomic Stabilization through an Employer of Last Resort," Journal of Economic Issues XLI(1): 93-134.

Gerards, R., J. Muysken, and R. Welters (2012), “Active Labour Market Policy by a Profit-Maximizing Firm,” British Journal of Industrial Relations 52(1): 136-157.

Godin, A. (2014), "Job Guarantee: A Structuralist Perspective," Revue de la Régulation 16(2): 1-27.

Harvey, P. (2005), "The Right to Work and Basic Income Guarantees: Competing or Complementary Goals?," Rutgers Journal of Law and Public Policy 2(1): 8-59.

Harvey, P. (2013), "More for Less: The Job Guarantee Strategy," Basic Income Studies 7(2): 3-18.

ILO (2012), Global Employment Trends for Youth 2012 Report. www.ilo.org/ getyouth

Imbert, C., and J. Papp (2015) "Labour Market Effects of Social Programs: Evidence from India's Employment Guarantee," American Economic Journal: Applied Economics 7(2): 233-263.

IMF (2015), "World Economic Outlook," Chapter 3, Box 3.5 on The Effects of Structural Reforms on Total Factor Productivity, 104-107. 
Judt, T. (2010), Ill Fares the Land. London: Allen Lane, Penguin.

Juniper J., T. P. Sharpe, and M. J. Watts (2014) "Modern Monetary Theory: Contributions and Critics," Journal of Post Keynesian Economics 37(2): 281-307.

King, J. E. (2001), “The Last Resort? Some Critical Reflections on ELR," Journal of Economic and Social Policy 5(2): 72-76.

Klink, J. J. L, van der, U. Bültman, A. Burdorf, W. B. Schaufeli, F. R. H. Zijlstra, S. Brouwer, and G. van der Wilt (2014), "Sustainable Employability - Definition, Conceptualization and Implications: A Perspective Based on the Capability Approach," Scandinavian Journal of Work, Environment and Work 40(5): 465-472.

Klosse, S. (2013), "How Little Red Riding Hood Copes with the EMU Wolf," in M. Visser and A. P. van der Mei (eds.), The Treaty on European Union 1993-2013: Reflections from Maastricht. Cambridge-Antwerp-Portland: Intersentia.

Klosse, S., and J. Muysken (2014), "Een inclusieve arbeidsmarkt vergt meer dan garantiebanen," Socialisme en Democratie 71(4): 64-72.

Kregel, J. (2009), "Mobilizing Domestic Resources: Employer of Last Resort as a National Development Strategy to Achieve the Internationally Agreed on Development Goals," International Journal of Political Economy 38(3): 39-57.

Marchal, S., and N. Van Mechelen (2016), "A New Kid in Town? Active Inclusion in European Minimum Income Schemes," Social Policy \& Administration, doi: 0.1111/spol.12177. Forthcoming

Maguire, S. (2015), "Young People Not in Education, Employment or Training (NEET): Recent Policy Initiatives in England and Their Effects," Research in Comparative and International Education 10(4): 525-536.

Marlier, E., and D. Natali (eds.) (2008), Europe 2020: Towards a More Social EU? Brussels: P.I.E. Peter Lang.

Minsky, H. P. (1965), “The Role of Employment Policy” in M. S. Gordon (ed.), Poverty in America. San Francisco, CA: Chandler Publishing Company, 175-200.

Mitchell, W. F. (1998), "The Buffer Stock Employment Model and the Path to Full Employment," Journal of Economic Issues 32(2): 547-555.

Mitchell, W. F. (2015), Eurozone Dystopia: Groupthink and Denial on a Grand Scale. Cheltenham: Edward Elgar.

Mitchell W. F., and J. Muysken (2008), Full Employment Abandoned: Shifting Sands and Policy Failure. Cheltenham: Edward Elgar.

Mitchell W. F., and J. Muysken (2010), "Full Employment Abandoned: Shifting Sands and Policy Failures," International Journal of Public Policy 5(4): 295-313.

Mitchell W. F., and M. Watts (2004), "A Comparison of the Macroeconomic Consequences of Basic Income and Job Guarantee Schemes," Rutgers Journal of Law and Urban Policy 2(1): 1-24.

Mitchell, W. F., and L. R. Wray (2005), "In Defense of Employer of Last Resort: A Response to Malcolm Sawyer," Journal of Economic Issues 39(1): 235-244.

Muellbauer, J. (2014), "Combatting Eurozone Deflation: QE for the People," Vox Europe, 23 December.

Natali, D. (2014), Social Developments in the European Union. Brussels: OSE.

Noguchi, E. (2013), "The Cost-Efficiency of a Guaranteed Jobs Program: Really? A Response to Harvey," Basic Income Studies 7(2): 52-65.

Ochel, W. (2005), "Welfare-to-Work Experiences with Specific Work-First Programmes in Selected Countries," International Social Security Review 58(4): 67-93. 
OECD (1994), Jobs Study. Paris: OECD.

OECD (2014), Employment Outlook 2014. Paris: OECD.

Palley, T. I. (2001), "Government as Employer of Last Resort: Can It Work?," Industrial Relations Research Association, 53rd Annual Proceedings, 269-274.

Papadimitriou, D. B., M. Nikiforos, and G. Zezza (2016), "How Long before Growth and Employment Are Restored in Greece?," Strategic analysis, Levy Economics Institute of Bard College.

Parker, S. K. (2014), "Beyond Motivation: Job and Work Design for Development, Health, Ambidexterity, and More," Annual Review of Psychology 65: 661-691.

Sawyer, M. (2003), "Employer of Last Resort: Could It Deliver Full Employment and Price Stability?," Journal of Economic Issues 37(4): 881-907.

Sawyer, M. (2005), "Employer of Last Resort: A Response to My Critics," Journal of Economic Issues 39(1): 256-264.

Standing, G. (2005), "Why Basic Income Is Needed for a Right to Work," Rutgers Journal of Law and Public Policy 2(1): 82-101.

Standing, G. (2013), "Why a Basic Income Is Necessary for a Right to Work," Basic Income Studies 7(2): 19-40.

Stiglitz, J. E., J-P. Fitoussi, P. Bofinger, G. Esping-Andersen, J. K. Galbraith, and I. Grabel (2014), “A Call for Policy Change in Europe," Challenge 57(4): 5-17.

Quirk, V., E. Allen, T. Andresen, A. Bill, B. Cook, B. Goldsmith, J. Juniper, R. La Jeunesse, W. F. Mitchell, J. Myers, M. Watts, R. Welters, and G. Wrightson (2006), “The Job Guarantee in Practice," Working Paper No. 15, Centre of Full Employment and Equity, University of Newcastle.

Tcherneva, P. R. (2012), "Beyond Full Employment: The Employer of Last Resort as an Institution for Change," Levy Economics Institute of Bard College, Working Paper No. 732.

Tcherneva, P. R. (2013), "The Job Guarantee: Delivering the Benefits That Basic Income Only Promises - A Response to Guy Standing," Basic Income Studies 7(2): 66-87.

Tcherneva, P. R., and L. R. Wray (2005), "Common Goals - Different Solutions: Can Basic Income and Job Guarantees Deliver Their Own Promises?," Rutgers Journal of Law and Urban Policy 2(1): 125-166.

Urbé, R. (ed.) (2012), The Future of the Welfare State: A Comparative Study in EU Countries. Freiburg im Breisgau: Caritas Europa Publication, Lambertus-Verlag.

Voegtlin, C., S. Boehm, and H. Bruch (2015), "How to Empower Employees: Using Training to Enhance Work Units' Collective Empowerment," International Journal of Manpower 36(3): 354-373.

Watt, A. (2013), "Europe's Unemployment Problem - Perhaps Half as Big Again," retrieved from http://www.socialeurope.eu/2013/04/europes-unemploymentproblem-perhaps-half-as-big-again/

Watts, M. J. (2010), "How Should Minimum Wages Be Set in Australia?," Journal of Industrial Relations 52(2): 131-149. 